\title{
Synthesis and Characterization of $o$-Carboranylthiolate Substituted 1,3,5-Triazines
}

\author{
Chai-Ho Lee, ${ }^{\star}$ Guo Fan Jin, Hyo-Suk Kim, ${ }^{\dagger}$ Hiroyuki Nakamura, ${ }^{\ddagger}$ and Jong-Dae Lee ${ }^{+*}$
}

\author{
Department of Chemistry and Institute of Basic Natural Science. Wonhitang Cniversity. Iksan, Jeonbuk $570-749$. Korea \\ ${ }^{*}$ E-mail: chaihoianonkwang ac. $k$ " \\ ${ }^{\dagger}$ Department of Chemistry, College of Natural Science. Chosun Lniversitw. Gwangiu 501-759. Korea \\ ${ }^{\star E}$-mail: jdleeiâchosun ack $\mathrm{k}$ \\ -Deparment of Chemistr. Facult of Science, Gakushin Cniversity. Toshima, Tokvo 171-8588, Japan \\ Received September 27, 2007
}

Key Words : Mercaptoundecalydrododecaborate. o-Carboranylthiolate, 1,3.5-Triazine, BNCT

Mercaptoundecahydrododecaborate $\left(\mathrm{B}_{12} \mathrm{H}_{1,} \mathrm{SH}^{2-}\right){ }^{l}$ known as $\mathrm{BSH}$. is a water-soluble divalent anionic boron cluster containing a SH subunit. exhibiting significantly low toxicity. For this reason. BSH has been successfully adopted as a potential agent in the area of boron neutron capture therapy (BNCT): ${ }^{2} o$-Carboranylthiol $\left(\mathrm{C}_{2} \mathrm{~B}_{11 j} \mathrm{H}_{11} \mathrm{SH}\right)^{3}$ is similar to $\mathrm{BSH}$ in terms of having a SH functional unit in a boron cluster (Figure 1). Thiol functional group can be useful to anchor $o$-carboranyl group to the 1.3.5-triazine ${ }^{4}$ unit. There are prototype reactions involving a nucleophilic triazine substitution with organic N, O and S-functional groups. Therefore, in this paper. $O$-carboranylthiolate was employed as a potential nucleophile to triazine network to generate $o$ carboranylthiolate functionalized-1.3.5-triazine derivatives such as 6-(o-carboranylthiolato)-2 4-bis[di(methoxyethyl)amino]-1.3.5-triazine (3) and 4.6-bis(o-carboranylthiolato)2-[di(methoxyethỵl)amino]-1.3.5-triazine (5-7).

Several $o$-carboranylthiolates. derived from $o$-carborane and methyl- and phenyl-o-carborane. were utilized as nu-

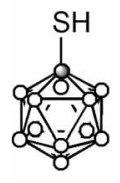

$0=\mathrm{B}$

$\mathrm{O}=\mathrm{BH}$

BSH

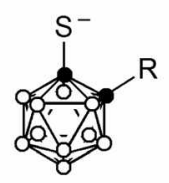

$$
\begin{aligned}
& \bullet=\mathrm{C} \\
& 0=\mathrm{BH}
\end{aligned}
$$

$\mathrm{O}=\mathrm{BH}$

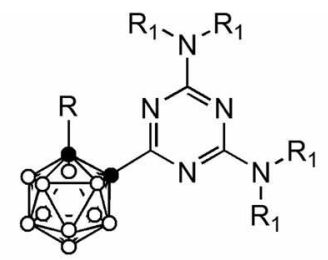

$\mathrm{R}=\mathrm{H}, \mathrm{CH}_{3}, \mathrm{C}_{6} \mathrm{H}_{5}$

$\mathrm{R}_{1}=\mathrm{CH}_{3}, \mathrm{CH}_{2} \mathrm{CH}_{2} \mathrm{Cl}$
Figure 1. BSH, o-carboranylthiolate, and o-carboranyl-1,3,5-triazine derivatives. cleophiles to generate mono- and bis( $\alpha$-carboranylthiolate) triazines. Chloro-1,3.5-triazines (2) were prepared according to the established synthetic protocols. Thus. 2 was obtained by reacting 1 with di(2-methoxyethyl)amine in 1:2 (Scheme 1). $o$-Carboranylthiolate was generated in sint by the reaction of $o$-carborane with an equimolar $n$-butyllithium. followed by addition of $S_{8}$ in anhydrous THF at $-78^{\circ} \mathrm{C}$. Subsequent reaction with chloro-1,3.5-triazines (2) generated the mono-substituted o-carboranythiolato-1.3.5-triazine (3) in $14 \%$ yield (Scheme 1).

In the ${ }^{1} \mathrm{H}$ NMR spectrum of 3 , diagnostic signals were observed for the ethy lene protons in $\mathrm{NCH}_{2} \mathrm{CH}_{2} \mathrm{O}$ at around $\delta$ 3.57-3.83. Key signals detected in the ${ }^{13} \mathrm{C}$ NMR spectrum of 3 include resonances at around $\delta 59.2-67.5\left(\mathrm{NCH}_{2} \mathrm{CH}_{2} \mathrm{O}\right)$. $62.9(C-\beta) .70 .4(C-c)$, and $161.7-175.6$ (triazine ring). A summary of selected physical and spectroscopic properties of 3 is presented in Table 1 .

Dichloro-1.3.5-triazine (4) was prepared according to the established synthetic protocols. Thus, 4 was obtained by reacting 1 with di(2-methoxyethyl)amine in $1: 1$ stoichiometry (Scheme 2). When dichloro-1.3.5-triazine (4) was reacted with two equivalent amount of lithium $o$-carboranyldithiolates in THF at $-78{ }^{\circ} \mathrm{C}$. the compounds 5-7 were formed in $31-92 \%$ yields (Scheme 2). In the ${ }^{1} \mathrm{H}$ NMR spectra of bis(o-carboranylthiolato)-1.3.5-triazine derivatives (5-7). diagnostic signals were observed for the ethylene protons of $\mathrm{NCH}_{2} \mathrm{CH}_{2} \mathrm{O}$ at around $\delta 3.50-3.95$. Key signals detected in the ${ }^{13} \mathrm{C}$ NMR spectra of 5-7 include resonances at around $\delta 59.1-79.6\left(\mathrm{NCH}_{2} \mathrm{CH}_{2} \mathrm{O}\right)$. 62.9-71.1 (C- $\left.\beta\right)$. 70.4$89.1(C-\alpha)$. and 161.7-175.6 (triazine ring). A summary of selected physical and spectroscopic properties of 5-7 is

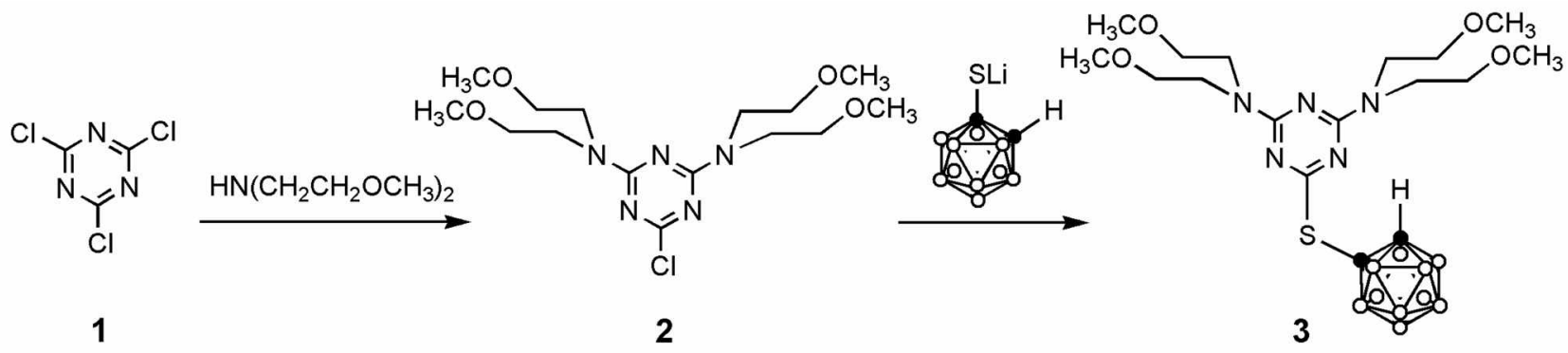

Scheme 1. Preparation of 6-(o-carboranylthiolato $)$-2,4-bis[di(methoxyethyl)amino]-1,3,5-triazine (3). 
Table 1. Summary of Selected Spectral Properties of the sulfur linked $o$-carboranylthiolato-1,3,5-triazine Derivatives 3, 5, 6, and 7
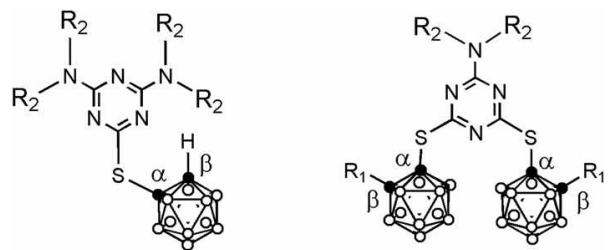

$\mathrm{R}_{1}=\mathrm{H}, \mathrm{Me}, \mathrm{ph}, \quad \mathrm{R}_{2}=\mathrm{N}\left(\mathrm{CH}_{2} \mathrm{CH}_{2} \mathrm{OCH}_{3}\right)_{2}$

\begin{tabular}{|c|c|c|c|c|c|c|c|c|}
\hline \multirow{2}{*}{ No. } & \multirow{2}{*}{$\begin{array}{c}\mathrm{Mp} \\
\left({ }^{\circ} \mathrm{C}\right)^{\sigma}\end{array}$} & \multirow{2}{*}{$\begin{array}{l}\text { Yield } \\
(\%)^{b}\end{array}$} & \multirow{2}{*}{$\begin{array}{c}\mathrm{IR} \\
v^{\prime}(\mathrm{B}-\mathrm{H})\end{array}$} & \multicolumn{5}{|c|}{$\operatorname{NMR}\left({ }^{1} \mathrm{H} / f^{3} \mathrm{C}\right)$} \\
\hline & & & & $\mathrm{NCH}_{2}$ & $\mathrm{OCH}_{2}$ & Triazine & $C(\alpha)$ & $C(\beta)$ \\
\hline \multirow[t]{2}{*}{1} & $54-56$ & 91 & & 3.57 & 3.85 & & & \\
\hline & & & & 58.9 & 70.1 & $\begin{array}{l}169.9 \\
164.8\end{array}$ & & \\
\hline \multirow[t]{2}{*}{3} & $112-$ & 92 & 2586 & 3.50 & 3.77 & & & 500 \\
\hline & 114 & & & 59.2 & 67.5 & $\begin{array}{l}175.6 \\
161.7\end{array}$ & 70.4 & 62.9 \\
\hline \multirow[t]{2}{*}{5} & $94-96$ & 14 & 2594 & 3.57 & 3.83 & & & 5.06 \\
\hline & & & & 59.2 & 67.5 & $\begin{array}{l}175.6 \\
161.7\end{array}$ & 70.4 & 62.9 \\
\hline \multirow[t]{2}{*}{6} & 138- & 62 & 2590 & 3.61 & 3.95 & & & \\
\hline & 139 & & & 59.1 & 75.3 & $\begin{array}{l}174.8 \\
161.9\end{array}$ & 80.1 & 71.1 \\
\hline \multirow[t]{2}{*}{7} & $51-52$ & 31 & 2592 & 3.64 & 3.95 & & & \\
\hline & & & & 59.1 & 79.6 & $\begin{array}{l}174.8 \\
161.9\end{array}$ & 89.1 & 71.1 \\
\hline
\end{tabular}

"Melting points are uncorrected. "Purified vields

presented in Table 1. Bis(o-carboranylthiolate) substitution is manifested by the X-ray structural study (Figure 2). Crystallograpic data for the structure reported here have been deposited with the Cambridge Crystallographic Data Centre (Deposition No. CCDC-671564). That data can be obtained free of charge wia http $/ /$ hwww.ccdc.cam.ac.uk/perl/ catreq.cgi.

Compounds 3. 5. 6. and 7 are moderately stable in air and decomposed slowly when they are in contact with light and moisture. Contrary to our expectation. toxicity of 0 carboranylthiolato-1,3.5-triazine derivatives $(3,5$. 6. and 7) was not improved. However. based on the results of in vitro studies. boron uptake in B-16 melanoma cells were found to be significantly increased (see Table 2).

\section{Experimental Section}

6-Chloro-2,4-bis[di(2-methoxyethyl)amino]-1,3,5-triazine (2). To a stirred solution of cyanuric chloride 1 ( $1.84 \mathrm{~g}$. $10 \mathrm{~mm}$ ol) and $N . N$-diisopropylethy lamine $(2.58 \mathrm{~g} .20 \mathrm{mmol})$ in THF. which was cooled to $-10^{\circ} \mathrm{C}$. was added di(2methosyethyl)amine ( $2.66 \mathrm{~g} .20 \mathrm{mmol}$ ) via a syringe. After the reaction temperature was maintained at $-10^{\circ} \mathrm{C}$ for $1 \mathrm{~h}$. the reaction mixture was wanmed slowly to room temperature. After being stirred for additional $12 \mathrm{~h}$. the reaction was quenched with distilled $\mathrm{H}_{2} \mathrm{O}(50 \mathrm{~mL})$. The crude product was extracted with diethyl ether $(30 \mathrm{~mL} \times 2)$. The organic layer was washed with $\mathrm{H}_{2} \mathrm{O}$. dried with anthydrous $\mathrm{Na}_{2} \mathrm{SO}_{4}$. and concentrated in vacuo to yield $3.62 \mathrm{~g}(96 \%)$ of 2. $\mathrm{Mp} .94-95{ }^{\circ} \mathrm{C}$. HRMS: $\mathrm{m} / \mathrm{z}$ : calcd for $\mathrm{C}_{15} \mathrm{H}_{28} \mathrm{ClN}_{5} \mathrm{O}_{4}$ : 377.1830: found: $377.1844[\mathrm{M}+\mathrm{H}]^{+}$. ${ }^{1} \mathrm{H}$ NMR $\left(\mathrm{CDCl}_{3}\right) \delta$ 3.33 (s, 12H). 3.58 (t. $J=5.5 \mathrm{~Hz} .8 \mathrm{H}$ ). 3.86 (t. $J=5.5 \mathrm{~Hz}$, $8 \mathrm{H}) .{ }^{13} \mathrm{C} \mathrm{NMR}\left(\mathrm{CDCl}_{3}\right) \delta 48.6,59.0 .70 .1 .164 .8,169.9$.

6-(o-Carboran-1-ylthiolato)-2,4-bis[di(2-methoxyethyl)amino]-1,3,5-triazine (3). To a stirred solution containing

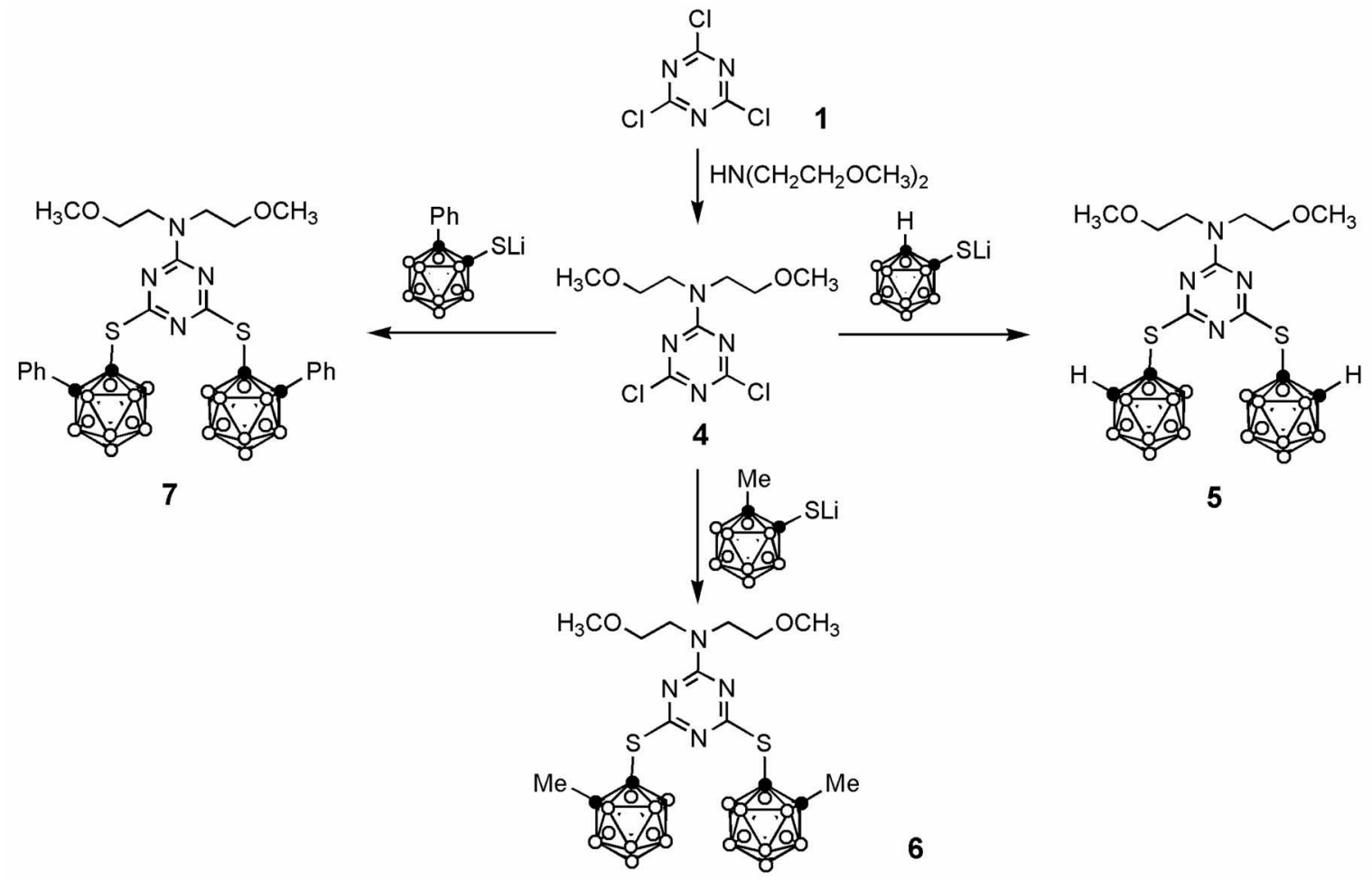

Scheme 2. Preparation of 4,6-bis(o-carborany]thiolato)-2-[di(methox yethyl)amino]-1,3,5-triazine (5-7). 


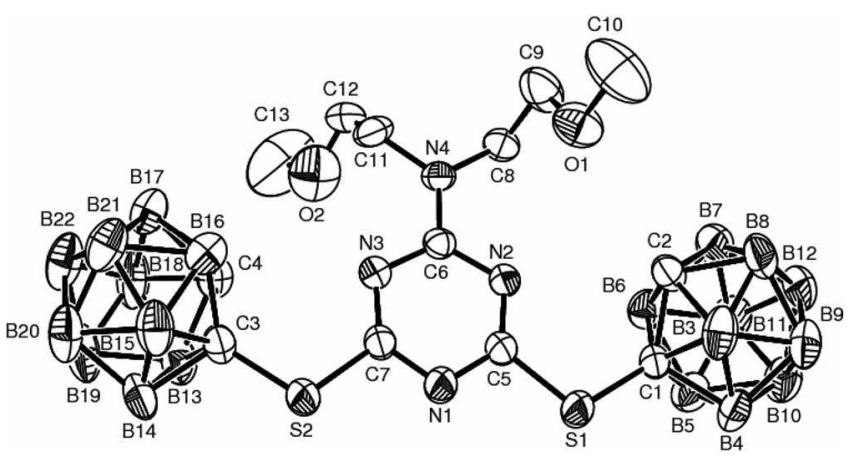

Figure 2. Molecular structure of compound 5. The themal ellipsoids are drawn at the $30 \%$ probability level.

Table 2. Cy totoxicity $\left(\mathrm{IC}_{50}\right)$ for $\mathrm{B}-16$ and Boron Uptake

\begin{tabular}{cccc}
\hline No. & Compound & $\mathrm{IC}_{50}(\mathrm{M})^{\alpha}$ & $\begin{array}{c}\text { Boron Uptake } \\
\left.\text { (t/g B } / 10^{6} \text { cells }\right)\end{array}$ \\
\hline 1 & 3 & $6.32 \times 10^{-5}( \pm 0.65)$ & $0.34 \pm 0.049$ \\
2 & 5 & $>100$ & $0.12 \pm 0.0028$ \\
3 & BPA & $4.49 \times 10^{-5}( \pm 0.30)$ & $0.12 \pm 0.0028$ \\
\hline
\end{tabular}

"B-16: B-16 melanoma cell. "Boron uptake by B-16 cells was detemined using the ICP-AES method. ${ }^{8}$

$o$-carborane $(0.14 \mathrm{~g} .1 \mathrm{mmol})$ was added $n-\mathrm{BuLi}(2.5 \mathrm{M}$. $0.4 \mathrm{~mL}$. $1 \mathrm{mmnol}$ ) in $20 \mathrm{~mL}$ of THF at $-78^{\circ} \mathrm{C}$ for $30 \mathrm{~min}$, and then added sulfur ( $\left.S_{\delta}\right)(0.032 \mathrm{~g}, 1 \mathrm{~mm}$ ol). After $6 \mathrm{~h}$, compound $2(0.38 \mathrm{~g}, 1 \mathrm{mmol})$ was added to the reaction mixture. The mixture was stirred at $-78^{\circ} \mathrm{C}$ for $30 \mathrm{~min}$. and then warmed to room temperature. After $12 \mathrm{~h}$. this reaction was quenched with distilled $\mathrm{H}_{2} \mathrm{O}(20 \mathrm{~mL})$. The mixture was extracted with diethyl ether $(20 \mathrm{~mL} \times 2)$. The organic layer was washed with $\mathrm{H}_{2} \mathrm{O}$. dried with anhydrous $\mathrm{Na}_{2} \mathrm{SO}_{4}$. and concentrated in vocio. The product 3 was isolated by flash column chrontatography (EA:Hx 1:4) in a $14 \%$ yield $(0.07$ g). Mp. $94-96^{\circ} \mathrm{C}$. HRMS: $\mathrm{m} / \mathrm{z}$ : calcd for $\mathrm{C}_{17} \mathrm{H}_{39} \mathrm{~B}_{11} \mathrm{~N}_{5} \mathrm{O}_{4} \mathrm{~S}$ : 519.3653 ; found: $519.361 \mathrm{l}[\mathrm{M}+\mathrm{H}]^{+}$. IR ( $\mathrm{KBr}$ pellet, $\mathrm{cm}^{-1}$ ) $v(\mathrm{~B}-\mathrm{H}) 2594 .{ }^{1} \mathrm{H}$ NMR $\left(\mathrm{CDCl}_{3}\right) \delta 3.33(\mathrm{~s}, 12 \mathrm{H}) .3 .57$ (t. $J=5.0 \mathrm{~Hz} .8 \mathrm{H}$ ). $3.83(\mathrm{t} . J=5.0 \mathrm{~Hz} .8 \mathrm{H}) .5 .06$ (s. $1 \mathrm{H}$ ). ${ }^{13} \mathrm{C}$ $\operatorname{NMR}\left(\mathrm{CDCl}_{3}\right) \delta 48.3 .59 .2,62.9 .67 .5 .70 .4,161.7,175.6$

4,6-Dichloro-2-[di(2-methoxyethyl)amino]-1,3,5-triazine (4). To a stirred solution of cyanuric chloride 1 (1.84 g. 10 mmol) and $N: N$-diisopropylethylamine $(1.3 \mathrm{~g} .10 \mathrm{mmol})$ in THF. which was cooled to $-10^{\circ} \mathrm{C}$. was added di(2-methoxyethyl)amine ( $1.33 \mathrm{~g} .10 \mathrm{mmol})$ via a syringe. After the reaction temperature was maintained at $-10^{\circ} \mathrm{C}$ for $\mathrm{l} \mathrm{h}$, the reaction mixture was warmed slowly to room temperature. After being stirred for additional $12 \mathrm{~h}$. the reaction was quenched with distilled $\mathrm{H}_{2} \mathrm{O}(50 \mathrm{~mL})$. The crude product was extracted with diethyl ether $(30 \mathrm{~mL} \times 2)$. The organic layer was washed with $\mathrm{H}_{2} \mathrm{O}$, dried with anhydrous $\mathrm{Na}_{2} \mathrm{SO}_{4}$. and concentrated in vacio to yield $2.56 \mathrm{~g}(91 \%)$ of 4 . Mp. 54-56 ${ }^{\circ} \mathrm{C}$. HRMS: $\mathrm{m} / \mathrm{z}$ : calcd for $\mathrm{C}_{2} \mathrm{H}_{1+} \mathrm{Cl}_{2} \mathrm{~N}_{4} \mathrm{O}_{2}: 280.0494$ : found: $280.0499\left[M+\mathrm{H}^{+}{ }^{1}{ }^{1} \mathrm{H} \mathrm{NMR}\left(\mathrm{CDCl}_{\hat{j}}\right) \delta 3.32\right.$ (s. $\left.6 \mathrm{H}\right)$. $3.57(\mathrm{t} . J=5.5 \mathrm{~Hz}, 4 \mathrm{H}) .3 .85$ (t. $J=5.5 \mathrm{~Hz}, 4 \mathrm{H}) .{ }^{13} \mathrm{C}$ NMR $\left(\mathrm{CDCl}_{3}\right) \delta 48.6 .58 .9,70.1$. 164.8. 169.9.

4,6-Bis(o-Carboran-1-y]thiolato)-2-[di(2-methoxyethy])aminol-1,3,5-triazine (5). To a stirred solution containing $o$ - carborane $(0.42 \mathrm{~g} .3 \mathrm{mmol})$ was added $n-\mathrm{BuLi}(2.5 \mathrm{M}$, $1.2 \mathrm{~mL}$ ) in $30 \mathrm{~mL}$ of THF at $-10^{\circ} \mathrm{C}$ for $45 \mathrm{~min}$, and then added sulfur ( $\left.\mathrm{S}_{8}\right)(0.096 \mathrm{~g} .3 \mathrm{mmol})$. After $12 \mathrm{~h}$. compound 4 $(0.42 \mathrm{~g} .1 .5 \mathrm{mmol})$ was added to the reaction mixture at -10 ${ }^{\circ} \mathrm{C}$. The mixture was stirred at $-10^{\circ} \mathrm{C}$ for $30 \mathrm{~min}$ then warmed to room temperature. After $12 \mathrm{~h}$. this reaction was quenched with distilled water $(30 \mathrm{~mL})$. The mixture was extracted with diethyl ether $(30 \mathrm{~mL} \times 2)$. The organic layer was washed with $\mathrm{H}_{2} \mathrm{O}$, dried with anlydrous $\mathrm{Na}_{2} \mathrm{SO}_{4}$, and concentrated in vocto. The product 5 was isolated by flash column chromatography (EA:Hx 1:4) in a $92 \%$ yield $(0.77$ g). Mp. $112-114^{\circ} \mathrm{C}$. HRMS: $\mathrm{m} / \mathrm{z}$ : calcd for $\mathrm{C}_{13} \mathrm{H}_{3,1} \mathrm{~B}_{20} \mathrm{~N}_{4} \mathrm{O}_{2} \mathrm{~S}_{2}$ 564.4141: found: $564.4100[M+\mathrm{H}]^{+}$. IR ( $\mathrm{KBr}$ pellet. $\mathrm{cm}^{-1}$ ) $v(\mathrm{~B}-\mathrm{H}) 2586 .{ }^{1} \mathrm{H}$ NMR $\left(\mathrm{CDCl}_{3}\right) \delta 3.26(\mathrm{~s} .6 \mathrm{H}) .3 .50(\mathrm{t}$. $J=5.0 \mathrm{~Hz} .4 \mathrm{H}$ ). 3.77 (t. $J=5.0 \mathrm{~Hz} .4 \mathrm{H}) .5 .00(\mathrm{~s}, 2 \mathrm{H}) .{ }^{13} \mathrm{C}$ $\operatorname{NMR}\left(\mathrm{CDCl}_{3}\right) \delta 48.3 .59 .2,62.9 .67 .5 .70 .4,161.7,175.6$.

6: Yield. $96 \%(0.85 \mathrm{~g}) . \mathrm{Mp} .110-112{ }^{\circ} \mathrm{C}$. HRMS: $\mathrm{m} / \mathrm{z}$ : calcd for $\mathrm{C}_{15} \mathrm{H}_{40}\left(\mathrm{~B}_{20} \mathrm{~N}_{4} \mathrm{O}_{2} \mathrm{~S}_{2}: 592.4454\right.$; found: 592.4497 $[M+\mathrm{H}]^{+}$. IR ( $\mathrm{KBr}$ pellet. $\mathrm{cm}^{-1}$ ) v(B-H) 2561. ${ }^{1} \mathrm{H}$ NMR $\left(\mathrm{CDCl}_{\mathrm{3}}\right) \delta 1.52(\mathrm{~s}, 6 \mathrm{H}) .3 .32(\mathrm{~s}, 6 \mathrm{H}) .3 .66(\mathrm{t} . J=5.5 \mathrm{~Hz} .4 \mathrm{H})$, 3.80 (t. $J=5.5 \mathrm{~Hz} .4 \mathrm{H}$ ). ${ }^{13} \mathrm{C}$ NMR $\left(\mathrm{CDCl}_{3}\right) \delta 21.4,49.2$, 56.1. 59.5. 71.2.73.7.162.4, 167.7.

7: Yield. $98 \%$ (1.05 g). Mp. $105-107^{\circ} \mathrm{C}$. HRMS: m/z: calcd for $\mathrm{C}_{25} \mathrm{H}_{44} \mathrm{~B}_{20} \mathrm{~N}_{4} \mathrm{O}_{2} \mathrm{~S}_{2}: 716.4767$; found: 716.4726 $[M+\mathrm{H}]^{+}$. IR ( $\mathrm{KBr}$ pellet. $\left.\mathrm{cm}^{-1}\right) v(\mathrm{~B}-\mathrm{H}) 2558 .{ }^{1} \mathrm{H}$ NMR $\left(\mathrm{CDCl}_{\mathrm{j}}\right) \delta 3.38$ (s. $6 \mathrm{H}$ ). 3.54 (t. $J=5.5 \mathrm{~Hz} .4 \mathrm{H}$ ). 3.75 (t. $J=5.5 \mathrm{~Hz} .4 \mathrm{H}) .6 .85-7.33(\mathrm{~m} .10 \mathrm{H}) .{ }^{12} \mathrm{C} \mathrm{NMR}\left(\mathrm{CDCl}_{3}\right) \delta$ 48.5. 54.2. 57.5. 68.2. 69.7. 158.2. 159.5. 160.7, 163.4. 168.7.

Crystallographic Data of Compound 5: $\mathrm{C}_{13} \mathrm{H}_{34} \mathrm{~B}_{2} \mathrm{~N}_{4} \mathrm{O}_{2} \mathrm{~S}_{2}$, Monoclinic, $P 2 \mathrm{~J} / n, \mathrm{a}=14.095(7) \AA \mathrm{b}=12.82 \mathrm{l}(7) \AA, \mathrm{c}=$ $18.244(9) \AA . \quad \beta=107.27(1)^{\circ} . V=3148(3) \AA^{3}, Z=4 . \quad D=$ $1.179 \mathrm{~g} / \mathrm{cm}^{3} . F(000)=1152 . R_{1}=0.0777, u R_{2}=0.2115$. Preliminary examination and data collection were performed using a Bruker SMART CCD detector system single-crystal $\mathrm{X}$-ray diffractometer equipped with a sealed-tube $\mathrm{X}$-ray source $(40 \mathrm{kV} \times 50 \mathrm{~mA})$ using graphite-monocluromated Mo $\mathrm{K} \alpha$ radiation $(\lambda=0.71073 \AA)$. Preliminary unit cell constants were detemined with a set of 45 narrow-frame $\left(0.3^{\circ}\right.$ in $(\omega)$ scans. The double-pass method of scanning was used to exclude any noise. The collected frames were integrated using an orientation matrix deternined from the narrowframe scans. The SMART software package was used for data collection. and SAINT was used for frame integration. ${ }^{5}$ Final cell constants were determined by a global refinement of $x y z$ centroids of reflections harvested from the entire data set. Structure solution and refinement were carried out using the SHELXTL-PLUS software package. ${ }^{\text {? }}$

Determination of $1 \mathrm{C}_{50}$. The boron compounds $(20 \mathrm{mg})$ was dissolved in $1.0 \mathrm{~mL}$ of DMSO. and the resulting solution was diluted with Eagle's MEM ( $10 \% \mathrm{FCS})$. or BPA ( $p$-boronophenylalanine) was directly dissolved in the same medium. In Falcon 3072 96-well culture plate. the cells $(1 \times$ $10^{3}$ cells/well) were cultured on five wells with the medium containing boron compounds at various concentrations ( 1 $100 \mathrm{ppm}$ ), and incubated for 3 days at $37^{\circ} \mathrm{C}$ in $\mathrm{CO}_{3}$ incubator. It is known that DMSO is non-toxic at the 
concentration lower than $0.5 \%$. We also confirmed by the control experiment that DMSO was non-toxic at the concentrations shown above. The medium was removed, and the cells were washed three times with PBS (-) (phosphatebuffered saline) and then MTS Assay for counting cells on Microplate reader. The results are presented as the concentration of agents that resulted in $50 \%$ of the cell number of untreated cultures (IC $\mathrm{C}_{00}$ ).

In vitro Boron Incorporation into B-16 Melanoma Cells. B-16 melanoma cells were cultured in Falcon 3025 dishes $(90 \mathrm{~mm} \phi)$. When the cells were grown to fill up the dish $\left(3.0 \times 10^{6}\right.$ cells/dish). the boron compounds $\left(1.0 \times 10^{-4}\right.$ M. $1.08 \mathrm{ppm}$ boron) and BPA $\left(1.0 \times 10^{-3} \mathrm{M}, 10.8 \mathrm{ppm}\right.$ boron) were added to dishes, The cells were incubated for 3 h at $37{ }^{\circ} \mathrm{C}$ in $20 \mathrm{~mL}$ of the medium (Eagle-MEM, 10\% $\mathrm{FBS}$ ). The cells were washed 3 times with $\mathrm{Ca}-\mathrm{Mg}$ free phosphate buffered saline [PBS $(-)$ ], collected by rubber policeman, digested with $2 \mathrm{~mL}$ of $60 \% \mathrm{HClO}_{4}-30 \% \mathrm{H}_{2} \mathrm{O}_{2}$ (1:2) solution and then decomposed for $1 \mathrm{~h}$ at $75^{\circ} \mathrm{C}$. After filtration with membrane filter (Millipore. $0.22 \mu \mathrm{ml}$ ), the boron concentration was deternined by using ICP-AES (Shinuadzu, ICPS-1000-III). Three replications of each experiment were carried out. The average of boron concentrations of each fraction was indicated in Table 2.

Acknowledgements. We are grateful to the KAERI for a grant (M206090001+1-07B0900-1+110). This work was also supported by the Korea Research Foundation Grant funded by the Korean Govenment (MOEHRD. Basic Research Promotion Fund) (KRF-2007-521-C00185).

\section{References}

1. (a) Elhanati. G.: Salomon. Y.: Bendel. P. Conter Letl. 2001. 172 . 127. (b) Awad, D.; Tabod, I.; Lutz, S.; Wessolowski, H.: Gabel, D. 1. Organonet. Chem. 2005, 690. 2732

2. (a) Nakamura. H.; Ueno. M: Lee. J.-D.: Ban, H. S.: Justus. E. Fant. P.: Gabel. D. Tetrahedron Lell. 2007, 48. 3151. (b) Sano. T. Bioconitgate Chem. 1999. 10. 905. (c) Aze\%. Y: Lork. E:: Duelchs. I.: Gabel. D. Tetrohedon Lett. 2004. 45. 3249. (d) Gabel. D.: Awad. D:; Schatfran. T.: Radovan, D.: Dărăban. D. Damian. L.: Winterhalter. M.: Karlsson. G; Edwards, K. Chem hedChem 2007, 2, 51 . (e) Justus. E.; Awad. D.: Hohnholt. M.: Schaffrant. T.: Edwards. K.: Karlsson1. G.: Dannian. L.: Gabel. D. Bioconjugate Chem. 2007. 18. 1287.

3. (a) Wang. T.: Zheng. C.: Maguire. T. A.: Hosmane. N. S. Orgonometallics 2003. 22. 4839. (b) Todd. J. A.; Caiazza, D.: Tiekink. E. R. T.: Rendina, L. M. horg. Chm. Acta 2003. 352. 208. (c) Laromaine, A.: Teixidor. F.: Kivekäs, R.: Sillanpăă. R:; Benakki. R.: Grüner. B.: Vitias. C. Dalton Trans. 2005. 1785.

4. (a) Azev. Y.: Slepukhina. I.: Gabel. D. Appl. Radiation Isotopes 2004. 61. 1107. (b) Woodhouse. S. L.: Ziolkowski. E. T.: Rendina. L. M. Dalton Trans. 2005, 2827.

5. (a) Maheswari, P. U.; Modec, B; Pevec. A.: Kozlevèar, B.: Massera, C; Gamez, P; Reedijk. J. Inorg. Chem. 2006, 45,6637 (b) Milton1. M. D.: Kumnar. N.: Sokhi. S. S.: Singh. S.: Singh. J. D. Tetrahedron Lett. 2004. 45 . 6453. (c) Milton. M. D.: Kumar. N. Sokhi. S. S.: Singh. S.: Maheshwari. M.: Singh. J. D.: Asnani. M.: Butcher. R. J. Tetrahedron Lett. 2004. 45,8941. (d) Shastin. A. V: Godovikova, T. I.: Korsunskii. B. L. Chem. Heterocyclic Comp. 2003. 39, 624

6. SLLART and SAINT. Bruker Analytical X-ray Division: Madison. WI. 2002

7. Sheldrick. G. M. SHELITLPLLS Software Package: Bruker Analytical X-ray Division, Madison, Wi. 2002.

8. Tietze. L. F.; Bothe. U.: Griesbach. U.; Nakaichi, M.: Hasegawa T. Nakamura. H: Yamamoto, Y. Chem. Bio. Chem 2001. 2. 326 